\title{
CONTENTS OF VOLUME 28
}

MARIO AHUES: A class of strongly stable operator approximations

CARLOS ALVAREZ and ALAN C. LAZER: An application of topological degree to the periodic competing species problem

BRLAN D. O. ANDERSON: See MICHAEL GREEN

R. S. ANDERSSEN: See A. R. DAVIES

D. D. BAINOV: See A. I. ZAHARIEV

MURRAY T. BATCHELOR: Sparse matrix factorizations of transfer matrices

462

A. BEN-ISRAEL and B. MOND: What is invexity?

JONATHAN M. BORWEIN: Generic differentiability of order-bounded convex operators 22

A. BROWN: Critical values for a nonlinear difference equation 340

A. BROWN: Ziebur's matrix equation for population growth

S. CHANDRA, B. D. CRAVEN and B. MOND: Generalized fractional programming duality: a ratio game approach

C. J. COLEMAN: A hybrid boundary integral/Taylor series approach to some nonlinear equations from fluid mechanics

I. L. COLLINGS: Two infinite-Froude-number cusped free-surface flows due to a submerged line source or sink

B. D. CRAVEN: A note on nondifferentiable symmetric duality

B. D. CRAVEN: See S. CHANDRA

GERHARD DANGELMAYR: Degenerate bifurcations near a double eigenvalue in the Brusselator

A. R. DAVIES and R. S. ANDERSSEN: Optimization in the regularization of illposed problems

FRANK DE HOOG and LAN H. SLOAN: The finite-section approximation for integral equations on the half-line

NEVILLE DE MESTRE: The long jump record revisited

R. J. DUFFIN, D. F. KARNEY and E. Z. PRISMAN: Apex duality for constrained optimization

R. R. EGUDO and B. MOND: Duality with generalized convexity

V. I. FABRIKANT: Closed form solution to some mixed boundary value problems for a charged sphere

M. D. GOULD: Polynomial identities for simple Lie superalgebras

MICHAEL GREEN and BRIAN D. O. ANDERSON: On the continuity of the Wiener-Hopf factorization operation

ANDREAS GRIEWANK: The "global" convergence of Broyden-like methods with a suitable line search

J. GUDDAT, H. TH. JONGEN and J. RUECKMANN: On stability and stationary points in nonlinear optimization

SVEN-ÅKE GUSTAFSON: Investigating semi-infinite programs using penalty functions and Lagrangian methods

S. HAYES: See K. L. TEO 
G. JEPPS: See K. L. TEO

H. TH. JONGEN: See J. GUDDAT

SUDHANGSHU B. KARMAKAR: A heuristic method for the determination of a Hamiltonian circuit in a graph

D. F. KARNEY: See R. J. DUFFIN

P. E. KLOEDEN: On the uniqueness of solitary Rossby waves

M. R. S. KULENOVIĆ, G. LADAS and A. MEIMARIDOU: Necessary and sufficient conditions for oscillations of neutral differential equations

KRISHNA KUNDU: See B. N. MANDAL

G. LADAS: See M. R. S. KULENOVIĆ

ALAN C. LAZER: See CARLOS ALVAREZ

B. N. MANDAL and KRISHNA KUNDU: A note on the singularities in the theory of water waves with an inertial surface

JOANNA MATULA: On an extremum problem

A. MEIMARIDOU: See M. R. S. KULENOVIĆ

B. MOND: See A. BEN-ISRAEL

B. MOND: See S. CHANDRA

B. MOND: See R. R. EGUDO

E. J. MOORE: See K. L. TEO

DAVID MUSTARD: Green manure and nitrogenous fertilizer-a two-sector optimalgrowth model

M. R. OSBORNE, S. A. PRUESS and R. S. WOMERSLEY: Concise representation of generalised gradients

M. A. PATHAN and YASMEEN: On partly bilateral and partly unilateral generating functions

E. Z. PRISMAN: See R. J. DUFFIN

S. A. PRUESS: See M. R. OSBORNE

J. RUECKMANN: See J. GUDDAT

J. M. SKOWRONSKI: Nonlinear model reference adaptive control

J. M. SKOWRONSKI: Nonlinear model reference adaptive control

IAN H. SLOAN: See FRANK DE HOOG

K. K. TAM: Initiation of thermal explosion by intense light: criticality dependence on data and parameters

K. L. TEO, G. JEPPS, E. J. MOORE and S. HAYES: A computational method for free time optimal control problems, with application to maximizing the range of an aircraft-like projectile

K. L. TEO, K. H. WONG and Z. S. WU: An optimal control problem involving a class of linear time-lag systems

R. S. WOMERSLEY: See M. R. OSBORNE

K. H. WONG: See K. L. TEO

Z. S. WU: See K. L. TEO

YASMEEN: See M. A. PATHAN

A. I. ZAHARIEV and D. D. BAINOV: On some oscillation criteria for a class of neutral type functional differential equations 